\title{
The effects of sand mining on rural communities
}

\author{
A. Mngeni ${ }^{1}$, C. M. Musampa ${ }^{1} \&$ M. D. V. Nakin ${ }^{2}$ \\ ${ }^{1}$ Department of Biological and Environmental Sciences, \\ Walter Sisulu University, South Africa \\ ${ }^{2}$ Risk and Vulnerability Science Centre, \\ Walter Sisulu University, South Africa
}

\begin{abstract}
Sand mining and its associated activities serves as a source of livelihoods for entire communities whilst on the other hand it can trigger conflicts and violation of human rights. This study is aimed at assessing the socio-economic impacts caused by sand mining in the rural communities of the Wild Coast of South Africa. In order to achieve this aim, focus group discussions, transect walks, and questionnaires were used. The results of the study indicate that sand mining serves as a source of income to communities through the generation of jobs for both youths and adults. Unfortunately, it also triggers tensions between government officials and members of the community. A holistic approach in resource management is proposed.
\end{abstract}

Keywords: sand, mining, livelihoods, community, Wild Coast.

\section{Introduction}

"There are currently more than 200 small to medium size 'sand-mining' sites on the Wild Coast, which are beginning to have devastating environmental impacts" [1]. Socio-economic effects are an amalgam form of environmental, social and economic factors. It is vital to note that quantifying the socio-economic effects is difficult given that sand mining habitually operates illegally. Therefore, one cannot simply conclude how much this type of activity contributes to the gross domestic product (GDP) of a country, being outside of taxation mainstreaming [2]. In contrast, Madyise [3] points out that sand mining contributes about $34 \%$ to the GDP of Botswana. In spite of this, it is of paramount importance to ascertain the 
socio-economic effects as that would help in decision making as development can only be achieved through sand mining for construction purposes of modern structures [3].

Sand mining activities have impacted, in one way or another, on the economic, social and environmental aspects of man in mining areas. However, many people resort to the trade of sand so as to earn a living. Since sand mining has economic gains, most community and traditional leaders sell community lands within their domains to miners. This is done because people derive their livelihoods from sand mining to ensure their survival from the natural resources available and accessible to them [4].

This situation is so due to an increase in demand for sand for construction purposes, but this also places enormous pressure on the environment. According to Kondolf et al. [5] sand mining is one of the direct and obvious causes of environmental degradation. Sand is one of the construction materials with high economic value. Wang et al. [6] they argue that sand mining activities have been rampant in many rivers, which has threatened the environment.

The demand for sand is increasing because its importance and role in construction is indispensable [7]. Extraction of sand is more likely to have ramifications around the environments of their occurrence. Extraction of sand from rivers, streams, flood plains, and channels conflict with the functionality of riverine ecosystems and some of the disturbances are from the mining methods and machines used [7].

Sand is used for all kinds of projects such as land reclamation, the construction of artificial islands and coastline stabilization, and these projects have economic and social value, but sand mining can also bring environmental problems [8]. Environmental problems occur when the rate of extraction of sand exceeds the rate at which natural processes generate the material [9].

Mining of natural aggregates such as sand serves as the main source of construction aggregate used throughout the world [10]. However, operations of sand mining whether small- or large-scale are disruptive to the environment [10]. You cannot protect the environment and mine it at the same time as the two variables are not mutually exclusive argues [2]. The Wild Coast is no exception regarding the environmental impacts given that community members from the Wild Coast communities were arrested for mining the sand in August 2014 and government officials in 2012 were locked up in the community when they were enforcing the law in terms of the Transkei Decree Act Number 9 of 1992 section 39 that clearly stipulates that any activity of clearing or removal of sand within $1 \mathrm{~km}$ from the high water mark is unlawful.

Madyise [3] affirms that sand like diamonds are natural resources highly demanded in construction industries which effects on the surrounding communities and the environment at large. Some of the important aspects of sand include: strengthening buildings when mixed with cement and concrete; plastering; mixing with concrete when making foundations; and moulding bricks for building of homes and rental houses which brings income to villagers [3]. Villagers build modern and durable houses at cheap cost because of the availability and accessibility of sand. The importance of sand also comprehends job creation 
$[3,12]$. The activity creates employment for youth and adults with youth being hired as sand loaders and adults mainly used as truck drivers.

Sand and gravel mining lead to an improvement in road networking systems. This improves the quality of access roads from gravel to tar roads. Madyise [3] went further to contend that sand when mixed with concrete is used to improve storm water drainage systems on sides of roads which carry water away during rainy season.

Sand mining causes conflicts including noise, dust, truck traffic, pollution and visually unpleasant landscapes [10]. On the other hand, Mattamana et al. [9] contend that sand mining has become an industry giving job opportunities for thousands of people. It also provides direct employment [3]. Recommendations made from this study serve as guidelines to decision makers who oversee sand mining activities. This study intended to identify the role played by natural resources in rural livelihoods. The study also exposes the impacts of sand mining on the livelihoods. It is important to note that there is lack of evidence on socioeconomic impacts from mining sites on the Wild Coast of South Africa, therefore this study seeks to close that gap.

\section{Materials and methods}

In order to elicit the views from the members of the community with regard to sand mining that is taking place in their areas and how they perceive the entire operation, focus group discussions were used to get general views of the local people. The focus group discussions were all conducted in IsiXhosa and answers were immediately transcribed into English. According to Bryman [13] the focus group method represents a form of group interview where there are several participants including the interviewer. It is a means to achieve some form of collective conscience or opinion of a group of people regarding their experiences of an issue or phenomenon under investigation.

The study was concerned with ascertaining the predominant feeling of the people about the activities of sand mining since it is more likely that differences may exist as to how different groups of people perceive the activities of the mining entities. The general idea was to gauge whether or not there exists a general consensus about how the communities feel about the mining operations and how these impact their livelihoods.

Community leaders and selected indigenous people who constitute sand mining committees in communities were selected to engage in the discussion that focused on impacts, coping mechanisms and management of the impacts. It was expected that since the discussion would be engaged and that consensus was likely to be reached at the end, the final account of the impacts of the activities of the mining activities would be authentic and largely reflect the actual situation obtaining on the ground [13].

The focus group discussions consisted of 5 to 12 members where each individual was given equal chance of voicing out his or her own perceptions about sand mining operations. For example, in Chwebeni the focus group discussion constituted of 12 people. In Mngazi, the committee constituted 7 members 
whereas in Coffee Bay, where there is no proper committee that manages sand mining, a focus group was constituted with 5 people who are the head man of the area together with two of his right hand men and one general community member, as well as a tour guide of the area. The choice was made by the headman. This choice was made on the basis that those are the people who help the headman to monitor and patrol voluntarily in the area in order to ensure that there is no one who is illegally mining sand in that area. Similarly, Madyise [3] had community members who volunteered to form committees, clusters and watch groups to monitor, supervise and guard sand mining in their communities.

The principal researcher went further to distribute questionnaires to each and every individual who participated in the focus groups so as to quantify the data gathered from the focus groups. Given the fact that indigenous people tend to be suspicious of strangers who come and ask them questions about their livelihood, they may sometimes refuse to provide correct information about the questions. All the questionnaires were written in English. However, the principal researcher together with research assistants translated the questionnaires to isiXhosa during the survey and transcribed the answers into English. The principal researcher went further to conduct transect walks. The walks were taken with the headmen; this choice was made on the basis that community leaders are often elderly people who have a better understanding of their village.

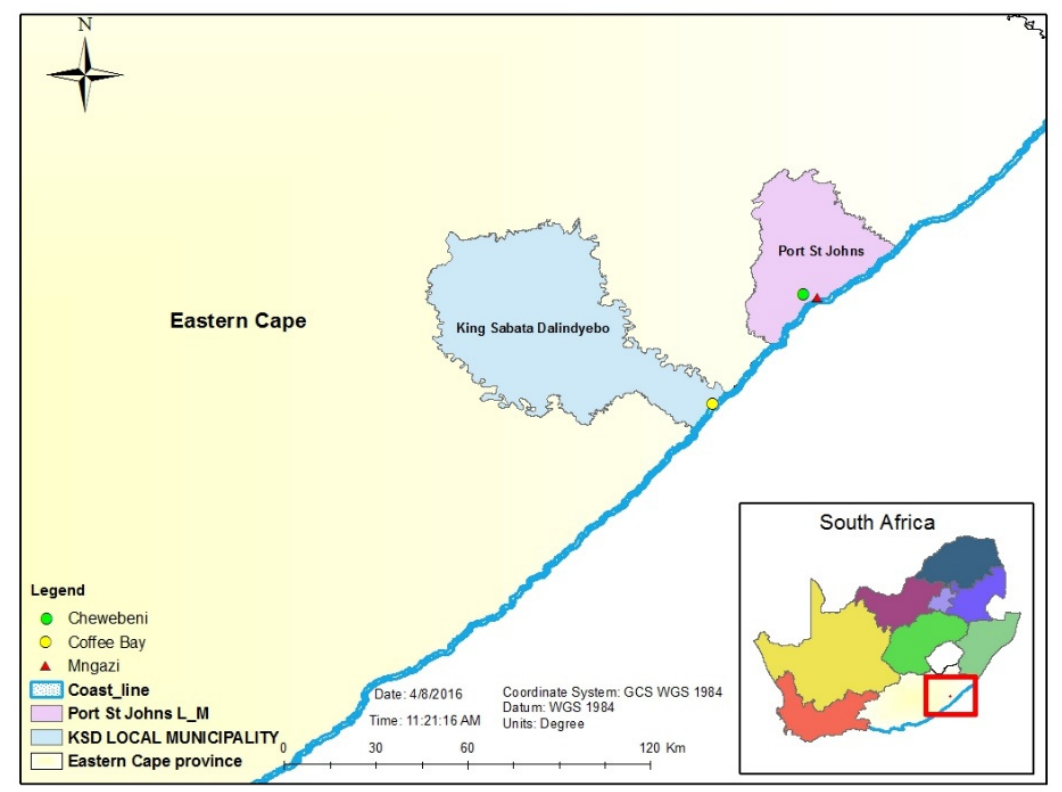

Figure 1: Map showing the study area.

Questionnaire surveys were distributed as a way of substantiating the information gathered through focus group discussions as well as transect walks. 
In Chwebeni 12 questionnaires were distributed to the members of the committee and 32 questionnaires were distributed to sand loaders and truck drivers. In Mngazi 1 questionnaires was given to the committee member and 6 questionnaires were given to truck drivers and sand loaders. In the case of Coffee Bay there were no questionnaires that were administered.

According to Mkando [14] transect walks are walks with local guides and analysts through an area, observing, asking, listening, discussing, learning about different zones, soil, land uses, vegetation, crops, livestock, local technologies, introduced technologies, seeking problems, solutions and opportunities and mapping and diagramming the zones, resources and findings. The principal researcher went further to interview sand miners mainly about financial implications and mining methods. In addition, the sand loaders were requested to provide information about the amount of money charged when selling the sand to consumers. ARC GIS 10.1 was used to produce the map of the study area and digital camera was used to catch pictorial evidence. Data analysis was achieved through the use of IBM SPSS software version 21 with windows (Chicago, Illinois, USA).

\section{Results}

The study identified profitability through job creation for community members in terms of the number of employees per village which was mostly associated with Chwebeni site and Mngazi in comparison with Coffee Bay as indicated in figure 2 below.

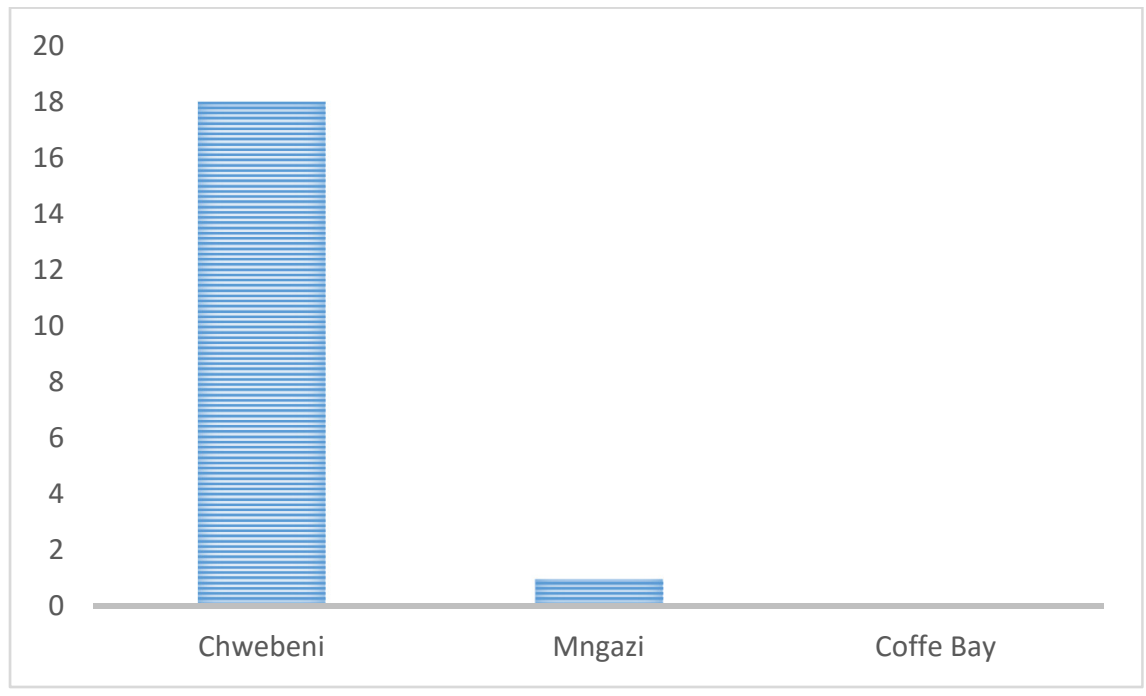

Figure 2: Number of employees per mining site. 
The study also revealed that Chwebeni and Mngazi have same amounts which are paid for the load before one can load the sand in each of the sites compared to Coffee Bay which is sitting at zero given that sand mining operates during odd hours. The study also revealed that the miners sell the sand to local communities at an average amount of R1300 per load. The study went further to divulge crime through turning a blind eye to environmental legislation as well as illegal concealing of people on sand mining sites.

\section{Discussion}

This study describes profitability in terms of number of employees, the amount paid for loading sand as well as the amount at which each load is being sold at in the study area. The results of the study reveal that sand mining in Chwebeni and Mngazi created more jobs than in Coffee Bay. The study further revealed that all the three communities are experiencing social impacts in terms of conflicts either with government officials or the illegal miners.

\subsection{Profitability}

Researchers deem sand mining as a job creator tool.

The study has revealed that commercial activities along the villages promote coastal sand mining and that generates income for villagers, thus the activities are difficult to stop. Because of this situation a sustainable sand mining management strategy is proposed. The reasons why sand mining activities are excessive depend on the socio-economic conditions of local people, mainly poverty and unemployment. These two factors are identified as the major driving forces behind sand mining; this is indicated by the presence of different age groups that are involved in the sand mining activity with teenagers being among the workers particularly as sand loaders. Likewise, Ikhsan et al. [15] suggest poverty and unemployment to be the main driving forces of sand mining. When asked about the importance of sand mining in their communities the respondents from Mngazi reported that:

- $\quad$ Sand mining serves as income generator for our community, we managed to build a community hall and there are people who earn living through the income generated through this industry so we cannot allow anyone to dictate to us that we should stop it especially these people from nature

Respondents from Chwebeni also declared that:

- This activity is our "Gold mine" because this is where we make money as there are no jobs anymore in our community. We manage to build churches for our community and we also contribute towards funeral arrangements for our people through the money that we collect from this industry.

The above two contentions clearly underpin the fact that sand mining is indeed an income generator for the communities as it has been noted from other studies such as the study by Madyise [3] in Botswana.

The Coffee Bay respondents on the other hand had dissimilar views and one respondent said: 
- $\quad$ This activity actually has to stop as soon as possible. This is going to kill our people because these people are mining the dune which serves as a buffer and now during high tide water comes close to us and soon this Ocean View hotel is going to be flooded.

The statement above indicates that the sand mining in coffee Bay is a serious illegal activity which is carried out by unknowns during odd hours. This was the case in the study by Madyise [3] in Botswana, advocates that the respondents from that area are thinking sustainably, they are not only considering their needs at present but rather they are cautious of the future impacts of the activity given that they even summoned government authorities to intervene on the matter.

The other factors that were found to promote sand mining in this region relate to profitability of the sand mining enterprises. This is evidenced by the variability between the amount paid for loading sand and the amount at which the load of sand is sold at. For example, in Chwebeni the 8 tonne truck costs R200 to load and the amount at which that load is sold at is roughly R1300 depending on the distance to which the load will be delivered. Similarly, other authors such as Mensah [16] and Onwuka et al. [4] are of the view that sand mining is being promoted by unemployment and high profitability. Ikhsan et al. [15] further contend that population growth is among the factors that encourage sand mining given the fact that as population grows the need for jobs is also escalating and that promotes more reliance on the exploitation of natural resources.

Sand mining serves as source of income to both Chwebeni and Mngazi communities. The community of Chwebeni has a committee of twelve members, of the twelve members there are three people who receive a monthly stipend from the money generated from the site and those members are chairperson, secretary and the treasurer, with each receiving an amount of R450.00 monthly. The other nine committee members receive payment only when they have done work such as going to the site and carrying out assessments, assisting in the maintenance of roads, site patrols, and each member gets paid an amount of R50 each day. They are also given six-day contracts that are usually issued out when there is a need to do so, such as opening a new road, maintenance of roads and separation of vegetation from the sand. Similarly, Madyise [3] also discovered that sand mining provides employment for youth as drivers and loaders and it also serves as a source of income to individuals who mine and sell sand and gravel or transport for people on small scale. Similarly, that has been the case in the study conducted by Sada and Shestha [12] where local people perceived sand mining as an easy means of money making.

According to the committee of Chwebeni, the secretary is always on site starting from $08 \mathrm{H} 00$ till $17 \mathrm{H} 00$. After $17 \mathrm{H} 00$ no trucks are allowed to enter the site unless there is a special arrangement. Each truck driver pays R200.00 depending on the size of the truck; for example, an 8 tonne truck is charged R200.00 and 4 tonnes R150.00. The money is paid to the secretary before loading and he is always on the site. Apparently the secretary uses the house which is near the sea and is about 100 to $150 \mathrm{~m}$ away from the high water mark. Therefore, the truck drivers need to drive closer to the house to pay the loading fee. When driving next to the house they damage the environment by loosening the soil and 
promoting soil erosion. When the trucks get stuck on a certain road the drivers decide to start a new route and their direction is towards the house that the secretary uses and that brings the effect towards the sea.

At Chwebeni the money collected each day by the secretary has to go to the headman's house to determine the amount collected; the registration numbers of the trucks that have loaded sand on that particular day and the amounts are also recorded and handed over to the headman. The collected money is banked in the local post bank. The money collected is used to pay the three executive members on a monthly basis, and it is also used to pay those who are hired on contract basis whether to maintain the road, separate vegetation from the sand or even hire a TLB machine to assist in opening a new road on site. The biggest chunk is used for building community churches, for example churches are funded with R12,000 yearly. The donation fee is not a once-off-payment but instead they pay it in instalments depending on their current balance in the bank. The other biggest chunk is used to assist whenever there is someone who has passed away in the community. The amounts paid to people differ according to age. For instance, if the deceased is above eighteen years the community contributes R5,000, whereas if the deceased is under eighteen the community contributes R3,000, and if the deceased is under ten years of age the community contributes R2,000.

This study has identified that the local people from the mining areas do not pay the loading fee they only pay for transportation. In other words, if one is from the mining area and she or he has transport of her or his own then that person can freely go to the site and load sand without paying. But if that person does not have his/ her own transport then that person will only pay R600.00 directly to the transport owner and not pay the loading fee.

The value of sand mining cannot be clearly determined because of the fact that they are operating without any formal permits from the relevant departments. This means that sand miners do not pay any tax to the South African Revenue Services (SARS). The truck drivers only get the permission for loading from the secretary and only pay the loading fee; this was the case in the study by Sada and Shestha [12] where sand mining was perceived to provide informal income for local residents. In addition to that, the headman revealed that they do not have permits despite the authorisation that they get from their chief. This therefore implies that sand mining is operating on the basis of black market. However, Ikhsan et al. [15] in their study in Merapi in Japan discovered that sand mining activity also gave an additional income to local governments through taxation. Therefore, it means that exploitation of materials provides rural areas with considerable opportunities for local economic development.

\subsection{Social problems}

The respondents from Chwebeni did not indicate any problems that are socially related to the sand mining activity, and government interventions are seen as a way of stopping them from what they are doing. When asked about the challenges that they experience with regard to sand mining one respondent reported that: 
- We do not have any problems here; this is all beneficial to us. The only problem here is the 'people from nature' who come here and dictate to us. One time they came into our area and went straight to our site and chased away the people who were mining and issued fines to them without even talking to us.

The above statements suggest that indeed sand mining is associated with wars and dictatorship and violation of human rights [17]. However, that situation triggered anger in the community to such an extent that when the government officials came back to explain the entire issue, the community decided to padlock the officials inside the Caguba royal household as a way of showing their anger towards the action that they took. This is a source of conflict between bureaucracy and communities and can have serious social and political repercussions. This forced the DEDEAT officials to allow the unlawful mining to continue without permits so that the community could unlock the gates. At Mngazi there are no problems that have been highlighted by the community. Musah [10] also highlighted sand mining as one of the sources of conflict amongst community members.

The respondents from Mngazi when asked about challenges faced with regard to sand mining they said the following:

- We don't have any challenges here; all that we need is assistance from government so that this can help us to generate a lot of money

On the other hand, the people of Coffee Bay stated that:

- We cannot actually say we have challenges because we are not the ones who are doing this activity here, maybe those people who do can provide you with better information even though we do not know who they are. So we can say from our side the challenges that we experience relate to health. For example, on about three occasions, we discovered bones of dead people on the site and we believe it is the miners that exposed those bones and we believe those are bones of people who might have killed each other during the festive season. Secondly this sand mining has caused the sea shore to come nearby.

The above lamentation reveals the fact that illegal sand operations trigger people's emotions and they are perhaps related to health issues [3]. Study conducted in Botswana also had a case of the same nature where residents were furious and asked that illegal miners be arrested. Also a study by Sada and Shestha [12] discovered that $75 \%$ of local residents were of the view that sand mining must stop immediately in their area due to its negative socio-economic effects.

This is similar to the view in Coffee Bay when they invited government officials from the Department of Mineral Recourses (DMR) and DEDEAT as well as O.R TAMBO District Municipality and King Sabata Dalindyebo Local Municipality to come and intervene in the matter. The officials together with the community reached a consensus that the site should be closed down with immediate effect. But because of the nature of the activity (illegal) the site is still operating in the sense that the miners are still continuing with sand mining at night. This has caused the community to again engage the DEDEAT officials and request proper fencing of the area so that the illegal miners cannot easily enter the site. 


\section{Perspectives for prevention, adaptations and interventions}

In order to mitigate some of the environmental impacts that are commonly experienced on the site, the community members should apply several methods. For example, one of the most common environmental problems that is experienced on the site includes destruction of the road which is caused by the trucks when they come onto and out of the site. As a mitigating measure, the community members use wood and stones to fill up the holes and reduce further soil erosion and land sliding. This study also identified a need for consideration of scientific management methods when carrying out road maintenance on the site as well as a need to register the entities that are carrying out sand mining so that they can pay tax so as to contribute towards local economic development.

\section{Conclusions}

This study looked at socio-economic impacts of sand mining as mirrored by profitability though in the face of chronic unemployment. The former is a reflection of high price parity between the loading fee and the selling fee together with the non-payment of taxes. Population growth also plays significant role by contributing to the lack of jobs. The study went further to divulge that sand mining underpins social problems which include conflicts that arise when the government officials try to implement environmental legislations without proper consultation with the community. Discovery of human remains in the sand mining sites is amongst the social impacts that were highlighted in the study. However, the communities react to the challenges through impact minimization strategies that include use of rocks and tree branches in order to fill up holes in damaged roads whilst on the other hand others invited authorities to intervene on matters that arise be beyond their powers. The study then calls for a holistic approach in community resource management.

\section{Acknowledgements}

We would like to acknowledge the financial assistance rendered by the Department of Science and Technology, through the Risk and Vulnerability Science Centre of Walter Sisulu University, and the National Research Foundation.

\section{References}

[1] Department of Economic Development, Environmental Affairs, and Tourism, 2013. Draft Spatial and Environmental Management Guidelines for the Wild Coast of the Eastern Cape Province Republic of South Africa.

[2] Chapman, E et al., Communities at Risk: Frac Sand Mining in Upper Midwest. Pan Solo \& Gro Smith eds. Newton. 
[3] Madyise, T. 2013. Case studies of Environmental Impacts of Sand Mining and Gravel Extraction for Urban Development in Gaborone. Master's Thesis. University of South Africa.

[4] Onwuka, S. V., Duluora, J. O., and Amaechi, I. E., 2013. Socio-Economic impacts of Sand and Gravel Mining activities in Nsugbe, Anambra state Nigeria. Albanian Journal of Agricultural Science Vol.12 (2), 229-235.

[5] Kondolf, G. M., Williams, J. G., Horner, T. C. \& Milan, D., 2008. Assessing Physical Quality of Spawning Habitat. American fisheries society symposium 65:000-000.

[6] Wang, Z., Ding, J., and Yang, G., 2012. Risk Analysis of Slope Instability of Levees under River and Sand Mining Conditions. Water Science and Engineering, V5 (3), 340-349.

[7] Kori, E., and Mthanda, H., 2012. An Assessment of Environmental Impacts of Sand and Gravel Mining in Nzhelele valley, Limpopo Province, South Africa.3rd International Conference on Biological, Environmental and Chemistry. IPCBEE. V. 46.

[8] Ashraf, M. A., Maah, J. M., Yusoff, I., Wadij, A., and Mahmood, K., 2011. Sand Mining Effects, Causes and Concerns: A Case study from Bestarijaya, Selangar Penisular. Malaysia. Scientific Research and Essays V6 (6), 12161231.

[9] Mattamana, B. A., Varghese, S., and Kichu, P., 2013. River Sand Inflow Assessment and Optimal Sand mining policy Development. International Journal of Emergency Technology and Advanced Engineering. V 3.

[10] Musah, J. A., 2009. Assessment of Sociological and Ecological Impacts of Sand and Gravel Mining; A case study of East Gonja District (Ghana) and Gunnorsholt (Iceland). Keldnaholt, 112 Reykjavik, Iceland. Land Restoration Training Program. Reykjavík, Iceland.

[11] Chevallier, R., 2014. Illegal Sand Mining in South Africa. Govermance of Africas Resource Programme.

[12] Sada, R. and Shestha, A., 2013. Report of State of Sand Mining at PerUrban Kathmandu. Case of Thavkhel VDC. Nepal.

[13] Bryman, A., 2008. Social Research Methods, 3rd edition, Oxford University Press; London.

[14] Mkando, Z., 2004. Crafting a Livelihood, Local-Level Trade in Mats and Baskets in Pondoland, South Africa. University of Western Cape.

[15] Ikhsan, J., Fujita, M., and Takebayashi, H., 2009. Sustainable Sand Mining in Merapi area using Groundsills.

[16] Mensah, J. V., 1997. Causes and Effects of Coastal Sand Mining in Ghana, Singapore Journal of tropical Geography, Vol.18 (1), 69-88. Department of geography, National University of Singapore and Blackwell Publisher Limited.

[17] Carrere, R., 2004. Mining: Social and Environmental Impacts. Uruguay: World Rain Forest. 